\title{
Impact of major gene resistance management for sunflower on fitness of Plasmopara halstedii (downy mildew) populations
}

\author{
Denis TOURVIEILLE de LABROUHE ${ }^{1}$ \\ Amandine BORDAT ${ }^{2}$ \\ Jeanne TOURVIEILLE ${ }^{3}$ \\ Emmanuelle MESTRIES ${ }^{4}$ \\ Pascal WALSER ${ }^{1}$ \\ Nachaat SAKR ${ }^{1}$ \\ Mireille DUCHER ${ }^{3}$ \\ François DELMOTTE ${ }^{5}$ \\ Felicity VEAR ${ }^{1}$ \\ ${ }^{1}$ Inra-UBP, \\ UMR 1095, \\ 234, avenue du Brézet, \\ 63100 Clermont-Ferrand, \\ France \\ 2 Inra-CNRS, \\ UMR 441, \\ BP 52627, \\ 31326 Castanet-Tolosan, \\ France \\ ${ }^{3}$ Inra-UBP, \\ UMR 1095, \\ 24, avenue des Landais, \\ 63177 Clermont-Ferrand, \\ France \\ ${ }^{4}$ CETIOM, ENSAT, \\ 18 Chemin de Borde-Rouge, \\ BP 32607 \\ 31326 Auzeville-Tolosane \\ France \\ ${ }^{5}$ Inra, \\ UMR santé végétale (Inra-Enita), \\ centre de recherches de Bordeaux, \\ la Grande Ferrade, \\ BP 81, 33883 Villenave d'Ornon cedex, \\ France
}

\section{FONDAMENTAL}

\begin{abstract}
Changes in virulence of Plasmopara halstedii populations under different major gene (PI) management strategies were studied over 5 years continuous cropping of one sunflower hybrid under netting cages. Strategies were monoculture of forms of the hybrid with 1 gene or with combinations of 2 genes, alternation of different genes, and mixtures of several different forms of the hybrid. Monoculture with single resistance genes led to loss of efficient resistance after 3 years, with high levels of disease and increased variability of the pathogen, whatever the PI gene used. Combinations of genes, alternation and mixtures gave longer term control of downy mildew. In particular, combinations of resistance genes coming from both female and male parents of the hybrid (such that even impurities had a resistance gene) gave the best control and least variation in pathogen virulence. Results are discussed with the object of durable control of downy mildew by all methods available.
\end{abstract}

Key words: durable resistance, aggressiveness, virulence, alternation, gene combinations, mixture

\section{Introduction}

Downy mildew has been observed in western European sunflower crops since 1960 (Leppik, 1962). The disease is caused by the Oomycete Plasmpara halstedii (Farl.) Berl. et de Toni, specific to sunflower and causing infection from soil or from seed. Different physiological races (pathotypes) can attack a variable range of sunflower genotypes. Nomenclature of these pathotypes is based on reaction of differential lines (Tourvieille de Labrouhe, 1999).

In France, no pathotype changes were observed until 1988, but since then new races have been observed, causing problems for the crop (data of Ministry of Agriculture - SPV). Changes have been followed by sampling of commercial varieties with known resistance genes. In the 1980s, all varieties grown in France carried $P / 1$ or $P / 2$, genes efficient against pathotype 100 (Mouzeyar et al., 1995). After 1988, with the appearance of pathotypes 710 and 703, breeders used $P 16$ or PI7 (Roeckel-Drevet et al., 1996). These two genes at present indistinguishable for their resistance efficiency, were most frequently used as they were simplest to distinguish in seedling tests. Considerable breeding efforts and registration of modified forms of known varieties, into which these new $\mathrm{Pl}$ genes were introduced by back crossing, resulted in more than half the area of sunflower being sown to varieties containing Pl6 or Pl7 by 2000 .

Since this date, new pathotypes able to overcome $P / 6$ and $P / 7$ have appeared. In areas in France where sunflowers are grown, with 2-3 year rotations and damp weather during sowing periods, use of only one resistance source probably led to the "selection" of new downy mildew pathotypes. Similarly, more recent use of another resistance gene cluster (PI5-P/8) (Bert et al., 2001) led to the observation of a pathotype able to overcome P/5 (pathotype 334) in 2004 (Tourvieille de Labrouhe, 2004).

The race between breeders and $P$. halstedii would probably be to the advantage of the latter, overcoming all the easily useable resistance genes if these are used singly, so new management strategies have had to be developed to limit pathogen changes or to reduce their economic consequences. Such strategies have already been developed to combat epidemics of various aerial parasites. de Vallavieille-Pope (2004) showed that a mixture of cereal cultivars reduced extent of attack, since, whereas some plants were susceptible, others were resistant. In addition, resistance induced by avirulent pathotypes could reduce infection by virulent pathotypes. McDonald and Linde (2002) showed that when a major resistance gene was present over a large area, there were increases in the frequency of virulent mutants. In addition to mixtures, there are 2 main strategies using major resistance genes to obtain durable resistance. The most common is to combine several genes in one variety (pyramiding), with the idea that the pathogen will not have the characteristics necessary to overcome 2 resistance genes simultaneously. The other possibility is to alternate, in time or space, the use of different major genes, to cause differences in 
selection pressure, so favouring particular virulence alleles only over short periods. Zhu et al. (2000) reported this strategy to control rice diseases.

Mixtures, gene pyramiding and alternation are all possible in sunflower to combat downy mildew since a number of $P /$ genes efficient against French downy mildew pathotypes are known and have been mapped, permitting the development of molecular markers, a help in their introduction by back cross programmes (Roeckel-Drevet et al., 1996; Bert et al., 2001; Vear et al., 2000; Bouzidi et al., 2002; Radwan et al., 2003; Vear et al., 2003; Dussle et al., 2004). This paper reports a 5 year experiment to determine the effects of mixtures, alternation and pyramiding on changes in pathogen virulence and aggressiveness, under conditions similar to those in the field.

\section{Materials and methods}

\section{Sunflower genotypes}

Four almost isogenic forms of a sunflower hybrid, differing only by their resistance to downy mildew (pathotypes 100 and 710) were used. They were obtained by crossing 2 inbred lines available in several forms:

L1 form a: carrying resistance from USDA line, "RHA274" (P/2), giving resistance to pathotype 100 .

L1, form b: developed from form a, into which resistance from USDA line "RHA340" (P/8), efficient against pathotypes 100 and 710, was introduced by back cross. Since $P / 8$ gives resistance to all known pathotypes and $P / 2$ and $P / 8$ segregate independently, it was not possible to determine whether this form carried both resistance genes or only P/8. This form of line 1 had the additional problem that, in seedling tests, resistance from "RHA340" is often of "Type II" (Tourvieille de Labrouhe et al., 2009), giving light to profuse sporulation on cotyledons, according to pathotype, infection conditions and genetic background of host plants. In the field this resistance appears effective.

L2 form a: no known resistance gene.

L2 form b: developed from form a, into which resistance from USDA line "HA335" (PI6), efficient against pathotypes 100 and 710, was introduced by back cross. This resistance is of "Type I" (Tourvieille de Labrouhe et al., 2009), generally with no visible sporulation.

The hybrids were:

- H1: L1a × L2a: susceptible 710;

$-\mathrm{H} 2$ : L1a $\times$ L2b: resistant 710;

- H3: L1b $\times$ L2a: resistant 710;

- H4: L1b $\times$ L2b: resistant 710 .

Only $\mathrm{H} 4$ had both parents with resistances to races 100 and 710 which were present in the experimental plots. The seed was from commercial productions with detectable impurities well below the accepted limits $(\mathrm{H} 1:<1 \%, \mathrm{H} 2:<4 \%, \mathrm{H} 3:<1 \%$ and $\mathrm{H} 4: 0 \%)$ but the few susceptible plants may have played an important role permitting the appearance of new pathotypes (Tourvieille de Labrouhe et al., 2005).

$P$. halstedii strains were identified from soil samples in which seed of an old susceptible hybrid, Airelle, were planted and maintained in conditions favourable for infection. To determine their pathotype, zoosporangia from infected plants were used to infect 9 international differential lines (Tourvieille de Labrouhe, 1999) and 3 other lines: "YVQ" (INRA, resistant to pathotype 710 but susceptible to pathotype 100), "XRQ" (INRA, resistant to all French pathotypes except pathotype 334) and "RHA340" (USDA, resistant to all known pathotypes).

Studies of aggressiveness, measured by duration of incubation period, percentage infection and hypocotyl length (Sakr et al., 2009), were made on INRA lines "FU" and "BT" which carry no known resistance gene, but which show quite high levels of quantitative resistance (Vear et al., 2008).

\section{Experimental plan (table 1)}

Six $9 \mathrm{~m} \times 7 \mathrm{~m}$ plots, under insect proof net cages, each containing about 300 plants at a density of about 50000 plants/ha. These plots were at INRA, Clermont-Ferrand (central France) and had previously carried either a cereal crop or sunflower with no downy mildew resistance genes. We found that only pathotypes 100 and 710 were present at the start of this experiment (Tourvieille de Labrouhe et al., 2005). Each year, these plots were irrigated to favour root infection $(100 \mathrm{~mm}, 7$ days after sowing) and then aerial downy mildew infections [by irrigations controlled by a humectostat to maintain liquid water on leaves (Tourvieille de Labrouhe et al., 1986)]. Plants were grown until just before flowering, when those with no symptoms were removed and those infected, cut and left in place to produce natural downy mildew inoculum the following year. Each plot was rotavated separately to mix inoculum in the soil and to prepare for the following sowing. The 5 year plan is shown in table 1. For the first 4 years, the 6 plots were:

- ReferenceH1: H1 (susceptible to pathotype 710) only

- MixtureH1234: 25\% of each hybrid

- Alternation: H1, H2 , H3, H4 were grown one after the other

- MonocultureH2: H2 (resistance from HA335: P16) only, resistant to pathotype 710

- MonocultureH3: H3 (resistance from RHA340: P/8) only, resistant to pathotype 710

- CombinationH4: H4 (both resistances to pathotype 710)

Over the 4 years, the number of diseased plants varied on each plot, so that contamination varied between years. The total numbers of diseased plants were: ReferenceH1: 737, MixtureH1234: 128, Alternation: 249, MonocultureH2: 82, MonocultureH3: 100 and CombinationH4: 6 (Tourvieille de Labrouhe et al., 2005).

In the fifth year, soil tests (Tourvieille de Labrouhe et al., 2008) were used to determine the parasite populations in each plot. Soil was taken

Table 1. Experimental plan over 5 years to determine the effects of major gene resistance management on changes in downy mildew pathogenicity, $\mathrm{H1}, \mathrm{H2}, \mathrm{H3}$ and $\mathrm{H} 4$ are quasi isogenic forms of a sunflower hybrid differing only for their downy mildew resistance genes.

\begin{tabular}{|lllllll|}
\hline Years & Plots $\left(\mathbf{6 5} \mathbf{m}^{\mathbf{2}}\right)$ & & & & \\
\cline { 2 - 7 } & MixtureH1234 & Alternation & ReferenceH1 & MonocultureH2 & MonocultureH3 & CombinationH4 \\
\hline $\mathrm{n}$ & $\mathrm{H} 1, \mathrm{H} 2, \mathrm{H} 3, \mathrm{H} 4$ & $\mathrm{H} 1$ & $\mathrm{H} 1$ & $\mathrm{H} 2$ & $\mathrm{H} 3$ & $\mathrm{H} 3$ \\
\hline $\mathrm{n}+1$ & $\mathrm{H} 1, \mathrm{H} 2, \mathrm{H} 3, \mathrm{H} 4$ & $\mathrm{H} 2$ & $\mathrm{H} 1$ & $\mathrm{H} 2$ & $\mathrm{H} 3$ & $\mathrm{H} 4$ \\
\hline $\mathrm{n}+2$ & $\mathrm{H} 1, \mathrm{H} 2, \mathrm{H} 3, \mathrm{H} 4$ & $\mathrm{H} 3$ & $\mathrm{H} 1$ & $\mathrm{H} 2$ & $\mathrm{H} 3$ & $\mathrm{H} 4$ \\
\hline $\mathrm{n}+3$ & $\mathrm{H} 1, \mathrm{H} 2, \mathrm{H} 3, \mathrm{H} 4$ & $\mathrm{H} 4$ & $\mathrm{H} 1$ & Soil test & Soil test \\
\hline
\end{tabular}


directly from the plots in trays which were each sown with 100 pregerminated seed of "Airelle" (seed were soaked for $2 \mathrm{~h}$ then maintained at $100 \mathrm{RH}$ and $20^{\circ} \mathrm{C}$ for $24 \mathrm{~h}$ ). After $48 \mathrm{~h}$ at $18^{\circ} \mathrm{C}$ in the dark, trays were immersed in water for $12 \mathrm{~h}$ then kept at $18{ }^{\circ} \mathrm{C}$ in light in a growth chamber for 14 days. To obtain separate sporulation from each seedling, plants were place in small transparent tubes for $24 \mathrm{~h}$. Those that sporulated were dried and frozen at $-80^{\circ} \mathrm{C}$ (Molinero-Demilly et al., 2005). At the same time, 100 seed each of $\mathrm{H} 1$ to $\mathrm{H} 4$ were infected to determine their reaction to the pathotypes present in each plot.

\section{Virulence test}

The isolates maintained at $-80^{\circ} \mathrm{C}$ were multiplied on the open pollinated variety Peredovik (no resistance gene) and then used to infect the 12 differential lines using the standard seedling test procedure described by Tourvieille de Labrouhe et al. (2000). Susceptibility was defined as either sporulation on leaves or heavy sporulation on cotyledons but none on leaves whereas resistance was complete absence of sporulation or only light sporulation on cotyledons. The same observation were made for $\mathrm{H} 1$ to $\mathrm{H} 4$ infected with the original strains and those sampled in the fifth year. Interpretation of observations of $\mathrm{H} 3$ and $\mathrm{H} 4$, carrying the gene $\mathrm{P} / 8$, derived from "RHA340" was subject to caution, as this resistance appears to develop slowly, such that during the seedling test there may be considerable sporulation on cotyledons, varying according to genetic background we have observed (data not shown) that, when a line carrying PI5 (in the same locus as P/8) was crossed with a number of susceptible lines, some of the hybrids showed a lot of sporulation, others much less.

\section{Measurement of aggressiveness}

The level of aggressiveness was calculated according to the method of Tourvieille de Labrouhe et al. (2009) from the virulence tests, made, for each $P$. halstedii isolate, on the differential lines, which showed the same reaction to all the isolates studied: D1, D2: susceptible to all isolates, D5D8, "XRQ" and "RHA340": resistant to all isolates. Aggressiveness varied from 0 to 1 from the following formula:

[(Number of plants of susceptible differentials sporulating on leaves)/ (number of plants infected)
+ (Number of plants of resistant differentials sporulating on cotyledons/ number of plants infected)].

$0=$ none of the seedlings of susceptible differentials showed sporulation on true leaves and none of the resistant differentials showed any sporulation at all.

$1=$ all the susceptible differentials showed sporulation on true leaves and all the resistant differentials showed some sporulation on cotyledons or hypocotyls.

To distinguish the behaviours of different isolates of pathotype 710 obtained from each plot, the methods of Sakr et al. (2009) were used to calculate the length of time between infection and sporulation on $80 \%$ of plants, maximum density of sporulation, $\%$ infection and hypocotyl length 13 days after infection.

All the seedling tests were made in closed growth chambers (permit N²003/DRAAF/70).

Statistical Analyses: All statistical analyses of the phenotypic data were performed using Stat Box $6.7^{\circledR}$ (GimmerSoft) software. In order to compare each characteristic measured for the different plots, the means obtained for each of their isolates were used as replications. The values obtained were submitted to a one-way analysis of variance (ANOVA). The Newman-Keuls test, which creates homogenous groups from the smallest significant amplitudes, was used to compare the means. Confidence limits were calculated at $p<0.05$.

\section{Results}

\section{Contamination of plants measured by laboratory tests on seedlings (table 2)}

Infection level: Observations of soil tests with a total of 270 seedlings of the completely susceptible hybrid control showed $30 \%$ infection for MonocultureH2 and MonocultureH3 and CombinationH4, 40\% for Alternation, $60 \%$ for MixtureH1234 and $90 \%$ for ReferenceH1.

Pathotypes present: Twenty four to 50 isolates were obtained for each plot, giving a total of 211 strains. Seven pathotypes were demonstrated, (300 1\%, 304 31\%, 314 7\%, 700 5\%, 704 3\%, $71039 \%$ et $71414 \%$ ) of

Table 2. Number of seedlings of the susceptible variety "Airelle" showing downy mildew symptoms (on a total of 100 infected), and number of Plasmopara halstedii strains of each pathotype collected in the 6 plots after 5 years experimentation.

\begin{tabular}{|c|c|c|c|c|c|c|c|}
\hline & \multicolumn{6}{|l|}{ Plots } & \multirow[t]{2}{*}{ Total } \\
\hline & ReferenceH1 & MixtureH1234 & Alternation & MonocultureH2 & MonocultureH3 & CombinationH4 & \\
\hline $\begin{array}{l}\% \text { of susceptible } \\
\text { seedlings }\end{array}$ & $89 / 100$ & $63 / 100$ & $40 / 100$ & $28 / 100$ & $24 / 100$ & $26 / 100$ & $270 / 600$ \\
\hline \multicolumn{8}{|l|}{ Number of strains } \\
\hline Pathotype 100 & 0 & 0 & 0 & 0 & 0 & 0 & 0 \\
\hline Pathotype 300 & 0 & 1 & 0 & 1 & 0 & 1 & 3 \\
\hline Pathotype 304 & 0 & 17 & 17 & 3 & 11 & 18 & 66 \\
\hline Pathotype 314 & 0 & 1 & 1 & 1 & 6 & 5 & 14 \\
\hline Pathotype 700 & 9 & 1 & 1 & 0 & 0 & 0 & 11 \\
\hline Pathotype 704 & 0 & 2 & 3 & 0 & 1 & 0 & 6 \\
\hline Pathotype 710 & 41 & 24 & 6 & 9 & 2 & 0 & 82 \\
\hline Pathotype 714 & 0 & 1 & 11 & 13 & 4 & 0 & 29 \\
\hline Total & 50 & 47 & 39 & 27 & 24 & 24 & 211 \\
\hline
\end{tabular}


which only 710 was present at the beginning of the trial and was already known for the Clermont-Ferrand region. Pathotype 100, although present at the beginning of the trial, was not found after 5 years.

Reactions of hybrids $\mathrm{H} 1$ to $\mathrm{H} 4$ : For each soil sample, the proportion of seedlings of each of the four hybrids, $\mathrm{H} 1$ to $\mathrm{H} 4$ gave an indication of the specific contamination capacity for each genotype (table 3).

$\mathrm{H} 1$ : this hybrid, susceptible to race 710 , present at the start of the experiment, was contaminated at a high rate by soil from the plots in which it was grown during at least part of the 4 years (ReferenceH1: 97\%, MixtureH1234: 79\%, Alternation: $37 \%$ ), but it was also contaminated by soil samples from the other plots.

$\mathrm{H} 2$ : This hybrid was contaminated at $35 \%$ by soil from MonocultureH2 and to a lesser extent by soil from MixtureH1234, Alternation and MonocultureH3.

H3: Only a few plants (<30\%) of this hybrid were infected, by soil from MonocultureH2, MonocultureH3, Alternation and CombinationH4.

$\mathrm{H} 4$ : Seedlings of this hybrid, which combined 2 sources of resistance to pathotype 710 were found to be contaminated at $55 \%$ by soil from the CombinationH4 plot, although in the field only 6 diseased plants had been observed over the 4 years. These seedlings were also contaminated at a similar level $(\approx 20 \%)$ to the other hybrids by soil from Alternation, MonocultureH 2 and MonocultureH3 plots.

Reaction of hybrids to strains isolated from the experimental plots: table 4 presents the results of tests with at least 100 seedlings. The 4 hybrids had given homogeneous results to the original strains of pathotypes 100 and 710 present at the start of the experiment, and for the strains of 710 isolated after 5 years, this behaviour was confirmed, $\mathrm{H} 1$ being susceptible and the other hybrids resistant. However, with the last strains, up to $5 \%$ of plants showed some downy mildew symptoms. For strains of pathotypes which apparently developed during the experiment, the 4 hybrids showed from 1 to $7 \%$ diseased plants with pathotype 304 but large and variable proportions of plants with disease symptoms when infected with pathotypes 314, 700, 704 and 714 (whereas the differential lines gave homogeneous reactions).

\section{Characterization of the pathogenicity of the 6 pathogen populations}

Pathogen population of ReferenceH1 plot: The soil tests had given $90 \%$ infection, from these seedlings. 50 isolates were studied, 41 were pathotype 710, 9 were of a different pathotype, 700. H1 was always completely susceptible, the other hybrids resistant. Thus, in this pathogen population, virulence varied little but the mean level of aggressiveness was high (0.38 \pm 0.04 , figure 1$)$.

Pathogen population of MixtureH1234 plot: The soil test had shown $60 \%$ infection. Fifty isolates were analysed, giving results for 47 of them, $60 \%$ of which infected $\mathrm{H} 1$. The other hybrids showed few susceptible plants. This pathogen population showed the greatest variability in virulence, with 7 pathotypes but 2 were most common: pathotype 710 (25 isolates) and 304 (16 isolates). Aggressiveness was moderate $(0.30 \pm 0.04)$.

Pathogen population of Alternation ( $\mathrm{H} 1$ then $\mathrm{H} 2$ then $\mathrm{H} 3$ then $\mathrm{H} 4)$ plot: There was $40 \%$ infection with the soil test and 39 isolates were charac-

Table 3. Percentage of seedlings of the 4 forms of the sunflower hybrid showing sporulation in soil tests according to origin of soil sample.

\begin{tabular}{|c|c|c|c|c|}
\hline \multirow[t]{2}{*}{ Plots } & \multicolumn{4}{|c|}{ Hybrids } \\
\hline & H1 & $\mathrm{H} 2$ & H3 & H4 \\
\hline ReferenceH1 & 97.22 & 2.78 & 0.00 & 0.00 \\
\hline MixtureH1234 & 79.31 & 11.67 & 3.36 & 5.66 \\
\hline Alternation & 36.84 & 20.98 & 24.17 & 18.02 \\
\hline MonocultureH2 & 26.11 & 35.49 & 16.26 & 22.07 \\
\hline MonocultureH3 & 36.77 & 13.14 & 28.68 & 21.42 \\
\hline CombinationH4 & 20.71 & 0.00 & 24.11 & 55.18 \\
\hline
\end{tabular}

Table 4. Identification of Plasmopara halstedii pathotypes isolated in year $n-1$ and $n+4$ and percentage of seedlings of $H 1, H 2, H 3$ and $H 4$, the 4 hybrid forms, showing sporulation with each pathotype.

\begin{tabular}{|c|c|c|c|c|c|c|c|c|c|c|c|c|c|c|c|c|}
\hline Pathotypes & D1 & D2 & D3 & D4 & D5 & D6 & D7 & D8 & D9 & XRQ & YVQ & Rha340 & H1 & H2 & H3 & H4 \\
\hline $100^{a}$ & $S$ & $S$ & $R$ & $R$ & $R$ & $R$ & $R$ & $R$ & $R$ & $R$ & $R$ & $R$ & $1 \%$ & $1 \%$ & $1 \%$ & $0 \%$ \\
\hline $304^{b}$ & S & $S$ & $\mathrm{R}$ & $\mathrm{R}$ & $\mathrm{R}$ & $\mathrm{R}$ & $\mathrm{R}$ & $\mathrm{R}$ & S & $\mathrm{R}$ & $S$ & $\mathrm{R}$ & $3 \%$ & $1 \%$ & $7 \%$ & $3 \%$ \\
\hline $314^{b}$ & S & S & $\mathrm{R}$ & S & $\mathrm{R}$ & $\mathrm{R}$ & $\mathrm{R}$ & $\mathrm{R}$ & $\mathbf{S}$ & $\mathrm{R}$ & $S$ & $\mathrm{R}$ & $12 \%$ & $9 \%$ & $77 \%$ & $40 \%$ \\
\hline $700^{b}$ & S & $S$ & $\mathbf{S}$ & $\mathrm{R}$ & $\mathrm{R}$ & $\mathrm{R}$ & $\mathrm{R}$ & $\mathrm{R}$ & $\mathrm{R}$ & $\mathrm{R}$ & $\mathrm{R}$ & $\mathrm{R}$ & $82 \%$ & $2 \%$ & $2 \%$ & $0 \%$ \\
\hline $710^{a}$ & $S$ & $s$ & $S$ & $S$ & $R$ & $R$ & $R$ & $R$ & $R$ & $R$ & $R$ & $R$ & $100 \%$ & $4 \%$ & $1 \%$ & $0 \%$ \\
\hline $710^{b}$ & S & $S$ & $\mathbf{S}$ & $\mathbf{s}$ & $\mathrm{R}$ & $\mathrm{R}$ & $\mathrm{R}$ & $\mathrm{R}$ & $\mathrm{R}$ & $\mathrm{R}$ & $\mathrm{R}$ & $\mathrm{R}$ & $96 \%$ & $5 \%$ & $2 \%$ & $1 \%$ \\
\hline $704^{b}$ & S & $\mathbf{S}$ & $\mathbf{s}$ & $\mathrm{R}$ & $\mathrm{R}$ & $\mathrm{R}$ & $\mathrm{R}$ & $\mathrm{R}$ & $\mathbf{s}$ & $\mathrm{R}$ & $\mathbf{s}$ & $\mathrm{R}$ & $73 \%$ & $68 \%$ & $87 \%$ & $72 \%$ \\
\hline $714^{b}$ & S & S & S & S & $\mathrm{R}$ & $\mathrm{R}$ & $\mathrm{R}$ & $\mathrm{R}$ & S & $\mathrm{R}$ & 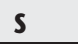 & $\mathrm{R}$ & $82 \%$ & $74 \%$ & $85 \%$ & $80 \%$ \\
\hline
\end{tabular}

H1-H4 = hybrids OLEOSEM (France); D1-D9 = international differential lines (Tourvieille de Labrouhe, 1999); XRQ, YVQ = lines INRA (France); RHA340 = line USDA (USA); alsolated year $n-1$; isolated year $n+4$ 


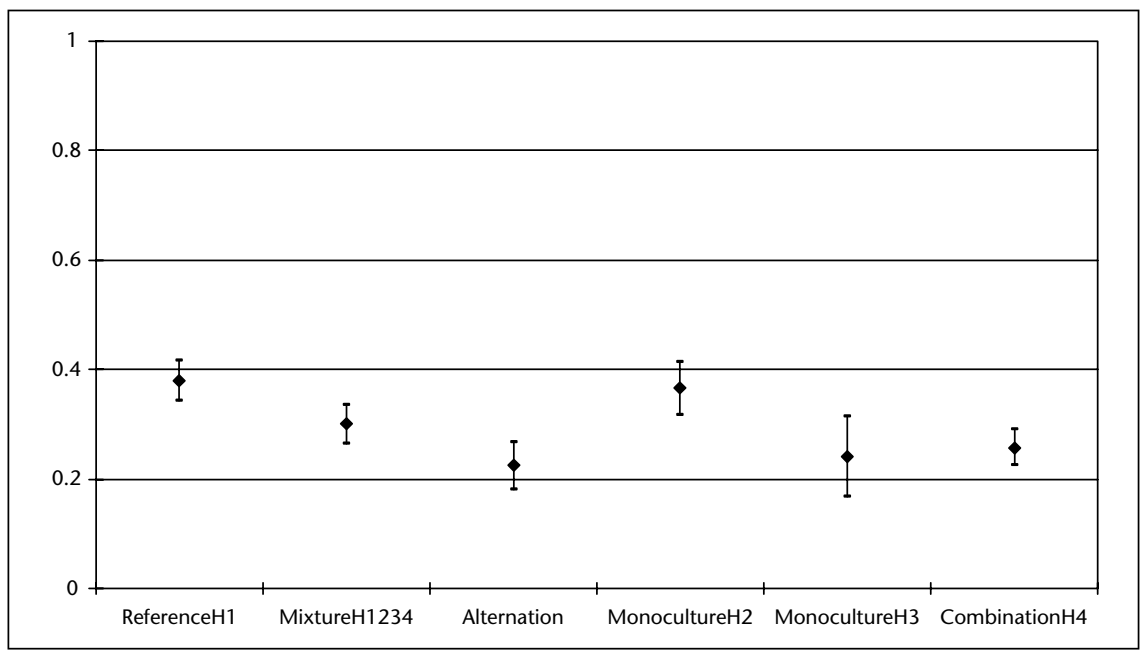

Figure 1. Level of aggressiveness of Plasmopara halstedii populations collected after 6 systems of resistance gene management.

terised, showing the presence of 6 pathotypes. Pathotype 304 was dominant (17 isolates), followed by pathotype 714 (11 isolates), and pathotype 710 remained present ( 6 isolates). The mean level of aggressiveness was low $(0.22 \pm 0.04)$

Pathogen population of MonocultureH2 plot: Less than $30 \%$ infection was observed with the soil test and only 27 isolates were characterised. There were 5 pathotypes, with predominance of pathotype 714 (13 isolates), but also 10 isolates of pathotype 710 . Agressiveness of this pathogen population was the same as that for ReferenceH1: $0.37 \pm 0.04$.

Pathogen population of MonocultureH3 plot: the soil test showed $24 \%$ infection and the 24 plants showed 5 different pathotypes, with 304 predominant (11 isolates), followed by pathotype 314 (6 isolates). Only 2 isolates were of pathotype 710 . Aggressiveness was low, $0.24 \pm 0.07$, similar to Alternation.

Pathogen population of CombinationH4 plot: Soil infection showed $26 \%$ attack, and the 24 isolates characterised were of only 3 pathotypes, 304 (18 isolates), 314 (5 isolates) and 1 isolate of pathotype 300. Aggressiveness was similar to Alternation and MonocultureH3: $0.36 \pm 0.07$.

\section{Analysis of the effects of varietal structure on strains of race 710}

To determine the effects of varietal resistances on aggressiveness, independently of virulence, the isolates of 1 pathotype, 710, from the different plots were compared. Taking the reactions of all the differential lines, the mean aggressiveness of isolates from the 5 plots did not differ statistically (figure 2). Isolates from Alternation were least aggressive (mean 0.30 compared with 0.39 for the other plots, but differences between isolates from this one plot were too great $(0.08$ to 0.50$)$ to permit distinction from the others.

To determine in more detail differences in aggressiveness, 4 isolates of pathotype 710 from each of the plots ReferenceH1, MixtureH1234, Alternation and MonocultureH2 were compared (table 5). There were no differences in mean values for \% infection and hypocotyl length, although MixtureH1234 and Alternation showed the greatest variability for the second character $(28.8-40.7 \mathrm{~mm}$ and $32.4-38.0 \mathrm{~mm}$ respectively). In contrast, strains from MixtureH1234 showed a significantly greater sporulation density $\left(10.5610^{5} \pm 1.00\right.$ zoosporangia/ cotyledon) than the isolates from other plots $\left(6.8710^{5} \pm .049\right)$.

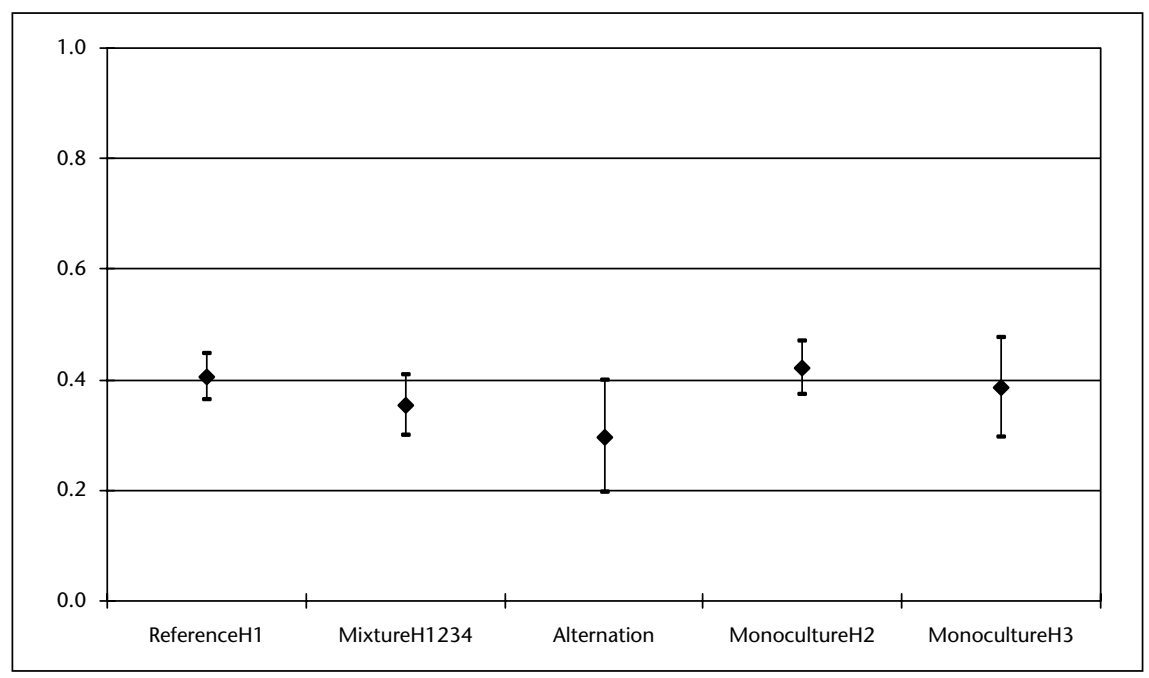

Figure 2. Level of aggressiveness of Plasmopara halstedii subpopulations of pathotype 710 collected after 5 systems of resistance gene management. 
Table 5. ANOVA inter-plots for 4 modes of PI resistance gene management to Plasmopara halstedii on the aggressiveness data measurements carried out on the sunflower inbred lines "FU" and "BT" (4 replications per plot that correspond to 4 strains of pathotype 710).

\begin{tabular}{|c|c|c|c|c|c|c|c|c|}
\hline \multirow[t]{2}{*}{ Plots } & \multicolumn{2}{|c|}{$\begin{array}{l}\text { Percentage infection } \\
(\%)\end{array}$} & \multicolumn{2}{|c|}{$\begin{array}{l}\text { Length of latent period } \\
\text { (days) }\end{array}$} & \multicolumn{2}{|c|}{$\begin{array}{l}\text { Sporulation density } \\
\text { (no. sporangia/cotyledon) }\end{array}$} & \multicolumn{2}{|c|}{$\begin{array}{l}\text { Length of the hypocoty } \\
(\mathrm{mm})\end{array}$} \\
\hline & FU & BT & FU & BT & FU & BT & FU & BT \\
\hline \multicolumn{9}{|l|}{ Reference } \\
\hline Mean & $99.3^{\mathrm{a}}$ & $100.0^{\mathrm{a}}$ & $9.5^{\mathrm{a}}$ & $8.2^{\mathrm{a}}$ & $7.0410^{5 b}$ & $9.2710^{5 \mathrm{~b}}$ & $38.8^{\mathrm{a}}$ & $34.0^{\mathrm{a}}$ \\
\hline Standard deviation & 0.5 & & 0.3 & 0.1 & 0.83 & 0.35 & 1.3 & 1.3 \\
\hline \multicolumn{9}{|l|}{ MixtureH1234 } \\
\hline Mean & $99.7^{\mathrm{a}}$ & $100.0^{\mathrm{a}}$ & $8.8^{\mathrm{b}}$ & $8.4^{\mathrm{a}}$ & $10.5610^{5 a}$ & $11.2110^{5 a}$ & $36.3^{\mathrm{a}}$ & $27.3^{b}$ \\
\hline Standard deviation & 0.3 & & 0.1 & 0.3 & 1.03 & 1.40 & 4.6 & 1.5 \\
\hline \multicolumn{9}{|l|}{ Alternation } \\
\hline Mean & $99.7^{\mathrm{a}}$ & $100.0^{\mathrm{a}}$ & $8.8^{\mathrm{b}}$ & $8.0^{\mathrm{a}}$ & $7.0810^{5 b}$ & $9.5210^{5 b}$ & $35.8^{\mathrm{a}}$ & $26.4^{\mathrm{b}}$ \\
\hline Standard deviation & 0.5 & & 0.2 & 0.1 & 0.64 & 0.40 & 2.3 & 1.2 \\
\hline \multicolumn{9}{|l|}{ MonocultureH2 } \\
\hline Mean & $98.7^{\mathrm{a}}$ & $100.0^{\mathrm{a}}$ & $9.4^{\mathrm{a}}$ & $8.1^{\mathrm{a}}$ & $6.5010^{5 b}$ & $8.1410^{5 b}$ & $36.3^{\mathrm{a}}$ & $32.8^{a}$ \\
\hline Standard deviation & 1.2 & & 0.2 & 0.1 & 0.42 & 0.40 & 0.9 & 3.8 \\
\hline
\end{tabular}

According to the Newmans-Keuls test means followed by the same letter (" $a$ " or " $b$ ") are not significantly different at $P=0.05$.

Incubation period was greater for strains from ReferenceH1 and MonocultureH2 (9.4 \pm 0.2 days) than for MixtureH1234 and Alternation (8.8 \pm 0.1 days).

\section{Discussion}

The soil test with the completely susceptible genotype gave a considerable number of isolates from all the plots, with from 50 strains identified for the ReferenceH1 plot to 24 strains for MonocultureH 3 and CombinationH4. This made it possible to develop some hypotheses concerning changes, selection and evolution in $P$. halstedii. Considering the resistances of the 4 hybrids to pathotypes 100 and 710 observed at the beginning of the programme, the number of strains identified from the soil test 4 years later was quite surprising.

\section{Effect of sunflower genotype on quantitative changes in contamination by $\mathrm{P}$. halstedii}

It was shown by Tourvieille de Labrouhe et al. (2005) that the changes observed in caged plots under single gene monoculture were similar to those observed in the field. The results confirmed that a single efficient resistance gene may be overcome quite quickly, with levels of attack exceeding $15 \%$. This is comparable with other pathosystems where single major genes are widely used in crops (de Vallavieille-Pope, 2004; McDonald and Linde, 2002). Over the 4 years of the experiment, the interest of alternation and mixture to reduce disease incidence was confirmed and the soil test in year 5 also showed low levels of infestation.

The soil test indicated the level of soil infestation (Tourvieille de Labrouhe and Walser, 2005). Generally it was correlated with the number of diseased plants observed during the first 4 years (Tourvieille de Labrouhe and Walser, 2005). However, the CombinationH4 plot only had 6 diseased plants (out of a total of about 1200: 0.5\% attack), whe- reas when susceptible seeds were sown in the soil, $25 \%$ were attacked, by races which were not present at the start of the experiment. It appears probable that this was due to the action of the resistance gene $P / 8$, which does not give "immunity" but "systemic acquired resistance" (Radwan et al., 2005), the parasite being able to infect roots (and cotyledons in seedling tests), such that some oospores (the conservation organ) are produced by sunflower roots and can thus cause contamination from the soil, although there are no symptoms on the shoot and crop growth is quite normal. However, the greater number of diseased plants in the plot MonocultureH3, with P/8 present alone, (100/1200: $8 \%$ attack), suggests that, when there are very favourable conditions for primary, seedling attack, in the genetic background of $\mathrm{H} 3$, some plants although containing $P / 8$, did not stop P. halstedii at the cotyledonary node. Vear et al. (1997) reported recombination within the Pl6 cluster such that lines were obtained which had lost resistance to pathotypes 100 and 300 while remaining resistant to pathotypes 700, 703 and 710 but in those observations, there was complete, uniform and pronounced susceptibility, which was not the case for the hybrid H3.

\section{Impact of sunflower genotype on evolution of pathogenicity among P. halstedii populations}

Analyses of the first 4 years of experiments demonstrated the appearance of 4 new virulences: 304, 314, 704 and 714. The soil test showed, in addition, pathotypes 300 and 700 . These 7 pathotypes are the same as those already isolated in other regions of France by the PlantProtection Service (SPV): pathotypes 300 and 700 in 1995, 304 in 2000, 314 in 2001 and 704 and 714 in 2002 (Delmotte et al., 2008) suggesting that the netted experimental plots reproduce changes which occur in commercial crops. It appears possible that all these races already existed with a low frequency among the original 710 and 100. Sunflower crops with resistance genes reduced the proportion of avirulent strains and selected those that were virulent on one or more 
forms of the sunflower hybrid. The fact that no pathotype 100 was isolated in the fifth year raises the question of its maintenance in the soil in the absence of completely susceptible varieties and its possible role in the changes in pathogenicity. Delmotte et al. (2008) analysed the genetic variability of $P$. halstedii pathotypes present in France but found that 100,300 and 304 were indistinguishable. On isolates from the plots in this experiment, Sakr (2008) reached the same conclusion. It may be suggested that race 100 strains have evolved towards 300 and 304 .

Changes in aggressiveness appear linked to those in virulence since there were no differences between isolates of pathotype 710 from the different plots

Analysis of the $P$. halstedii strains isolated from hybrids $\mathrm{H} 1$ to $\mathrm{H} 4$ showed considerable differences:

- The pathogen isolates from the ReferenceH1 plot showed little diversity, only pathotypes 710 and 700 were identified (both of which are virulent on $\mathrm{H} 1$ ), although $\mathrm{H} 1$ was susceptible to 3 of the 5 other pathotypes encountered elsewhere in the experiment. Thus, in the absence of selection pressure, P. halstedii appears to change very little. It was not possible to determine whether the pathotype 700 strains came from loss of a virulence factor in pathotype 710 or gain in several factors from pathotype 100, allowing them to develop on $\mathrm{H} 1$. The population in this plot showed a high level of aggressiveness, although the strains of pathotype 700 were less aggressive than those of 710 (figure 3).

- Two pathotypes, 710 and 714, were dominant in MonocultureH2. Pathotype 710 is not virulent on $\mathrm{H} 2$, but it may have been maintained on impurities (5\%), since the resistance of this hybrid (PI6) allows little mycelium growth in sunflower roots. In contrast, pathotype 714, which made up 50\% of strains identified probably developed because of the selection pressure due to the presence of the single major gene Pl6. The absence of pathotype 704, which could have developed for the same reason, was probably due to its generally weaker aggressiveness. These pathotype changes appear as an adaptation of the parasite to the host present since $\mathrm{H} 2$ showed the highest level of infection in the soil test.

- For MonocultureH3, the 2 strains of pathotype 710 could have been multiplied on impurities, or could have come from mycelial growth in the roots of H3. Two pathotypes were predominant, 304 (11 isolates) and 314 ( 6 isolates). In the soil test, $\mathrm{H} 3$ showed considerable sporulation not with these pathotypes but with 704 and 714 although few strains of these last pathotypes were identified in this plot. Pathotype identifications were based on the nine differential lines and can be accepted as exact. In contrast, the inconsistency of results with $\mathrm{H} 3$, which should be resistant to all known pathotypes underlines the difficulty of interpreting seedling tests for $P / 8$, which may give more or less rapid activation of resistance, and thus more or less sporulation on cotyledons, according to genetic background. A hypothesis to explain the predominance of 304 and 314 could be that, in the convertion of the parental line L1b, P/2 was lost, since it was hidden by $P / 8$, leaving an allele with a high level of susceptibility to pathotypes $3 \mathrm{xx}$, as was reported for lines in which Pl6 was cut giving susceptibility to the same pathotypes (data not shown). Since, in the genetic background of $\mathrm{H} 3, \mathrm{P} / 8$ resistance appears to take time to become efficient, pathotypes 304 and 314 may have been able to develop sufficiently to be maintained in roots at a high frequency.

- Among the pathogen population from the CombinationH4 plot there were no 710 strains, perhaps because the level of impurities was very low $(<1 \%)$, perhaps also because the gene Pl6 was present and this stopped growth of race 710 mycelium in roots. The most common pathotypes were 304 (75\%) and 314 (21\%), to which Pl6 does not give resistance and which can grow in the roots of plants containing $P / 8$. Although the same is true for pathotypes 704 and 714 , the last two were not identified, perhaps because of weaker aggressiveness, as reported by Sakr (2008).

- The greatest variability of pathotypes was obtained from the MixtureH1234 plot, with more than 50\% of pathotype 710 , which could be explained by the presence each year of the susceptible hybrid $\mathrm{H1}$, but also 6 other pathotypes. H2 was susceptible to 4 of these $(304,314$, $704,714)$, which could probably also grow on the roots of both $\mathrm{H} 3$ and H4, while pathotypes 300 and 700 could grow in roots of $\mathrm{H} 3$. This maintenance of variability by pathogen growth on the roots of resistant plants could explain why there was no increase in percentage attack during the first four years.

The Alternation plot also gave a wide variability, with 6 pathotypes in the soil test. The pathotypes present in diseased plants each year were in agreement with the resistance genes present in the different hybrids: in the first year, pathotype 710 was found on $\mathrm{H} 1$, in following years, few diseased plants were observed and the other pathotypes corresponded with the susceptibility of $\mathrm{H} 2$ to pathotypes $x \times 4$ or to levels of impurities in the other hybrids (Tourvieille de Labrouhe et al., 2005). In the soil test, only 6 isolates of pathotype 710 were obtained, suggesting that this pathotype had weaker aggressiveness and fitness than the other so that it was not maintained in roots in the absence of a susceptible variety.

Studies of possible variation in aggressiveness among isolates of pathotype 710 according to the sunflower hybrids grown showed differences for 2 characters: sporulation density and length of latent period. Strains from the MixtureH1234 plot had the greatest sporulation densities, although not at the highest levels observed by Sakr (2008). This plot was the only one that showed a significant number of diseased plants each year when $75 \%$ were resistant. In this situation, there was a selective advantage for strains producing a lot of spores, since this increased the likelihood that some would land on susceptible plants and give secondary infections which were observed quite frequently in year $n+3$ (Tourvieille de Labrouhe et al., 2005). In the ReferenceH1 plot, since pathotype 710 was in contact with susceptible plants, there was no selective advantage of increased spore production and in Alternation and MonocultureH2, few plants became diseased, and the strains obtained showed no change in sporulation density. Length of latent period was reduced for strains from MixtureH1234 and Alternation, the 2 plots where all four hybrid forms were grown at some time, but in which only 2 isolates were obtained. The selection pressure applied by the presence of major gene P/8 may have led to the slight increase in aggressiveness. However, the 4 sunflower hybrids were nearly isogenic except for the $\mathrm{Pl}$ genes, so it is logical that most selection was on virulence rather than aggressiveness, in agreement with Sullivan et al. (2005) who showed that pathotype specific resistances in tobacco had no selective effect on aggressiveness in Phytopthora parasitica var nicotinae.

Loss of efficiency of single major gene resistances was reported by Tourvieille de Labrouhe et al. (2005). In the present study, the variability of virulence which appeared when Plgenes were used singly, (MonocultureH2, MonocultureH3) confirms that the parasite adapts to host genotype and that other strategies managing downy mildews resistance genes are necessary to provide durable control of the disease:

- Mixtures: The MixtureH1234 was obtained by mixing equal proportions of the 4 forms of the sunflower hybrid. The presence of $25 \%$ of plants susceptible to race 710 was probably the reasons that this pathotype was maintained over the 5 years of the experiment. However, it did not avoid development of new virulences (6 other pathotypes). Multi-line and multi-hybrid varieties have been used, or suggested for use, in other crop-pathogen combinations in order to limit quantities of inoculum, which can be the source of new virulences and to give protection of susceptible plants by surrounding them with resistant plants (Lannou and Mundt, 1997, Mundt et al., 2002). In the case of sunflower downy mildew, primary infection comes from the soil so the level of infestation 
depends mainly on the level of infestation of the plot and whether climatic conditions are favourable. Tourvieille de Labrouhe et al. (2005) showed the same level of attack of $\mathrm{H} 1$ by pathotype 710 when it was grown alone or as part of the mixture, so the mixture did not give any protection. Another possible interest of a mixture could be that the presence of susceptible plants would limit pressure of selection on the pathogen by allowing least virulent isolates to be multiplied and develop, at the expense of more virulent isolates. However, this would increase the quantity of inoculum present and thus the possibility of appearance of rare virulences, mutants or recombinants. The soil tests carried out in year $\mathrm{n}+4$ showed that almost half the isolates were of 6 new pathotypes, confirming that this hypothesis did not apply for sunflower downy mildew. In addition, multihybrid varieties would require breeders to develop several forms of each hybrid causing increased cost without additional sales and problems of traceable maintenance of the different seed lots.

- Alternation: This is based on the inclusion in the rotation of varieties with different sources or types of resistance to diversify selection pressure on the parasite (Holt and Chancelor, 1999). The present results showed that this strategy limited the number of plants attacked in most years, in spite of a high level of attack the first year. The possible interest of this strategy is that isolates favoured one year are confronted with a different resistance the following year in the presence of which they cannot multiply, but they need to remain present at low levels if resistance genes are to be durable. In $n+4,15 \%$ of isolates in the Alternation plot were of the initial pathotype, 710 . Since $P$. halstedii oospores remain viable in the soil for up to 10 years and most sunflower crops will have a few impurities or volunteer plants, there is little probability that a pathotype present can be eliminated but, with a quite long rotation the frequency of virulent pathotypes should be reduced if the resistance gene to which they are virulent is not used. In this plot, only $41 \%$ of isolates collected in year $\mathrm{n}+4$ were virulent on $\mathrm{H} 1$ grown the first year and susceptible to all the pathotypes present at that time.

Since main losses to the sunflower crop come from primary infections from the soil, alternation should concern the varieties grown in each field. For a farmer, this would require that the resistance genes in each variety should be marked on the seed bag. Breeders could develop different forms of a variety with different resistance genes, and obtain additional sales since the same variety could be grown several times consecutively in a rotation.

- Combination (or pyramiding): In this case several efficient major resistance genes are combined in one variety, as for $\mathrm{H} 4$ which contained Pl6 and P/8, both resistant to race 710 . When $\mathrm{H} 4$ was grown continuously, for the first 2 years no diseases plants were observed and pathotype 710 was not found in year $n+4$. In this hybrid, both parents contained a Plgene, in particular the female line contained Pl6 so even if there were impurities these would have been resistant to race 710 . In addition, the presence of Pl6 meant that isolates of pathotype 710 could not grow in the roots of $\mathrm{H} 4$ plants, when they could in those of $\mathrm{H} 3$ (P/8 alone), so that there was little inoculum from which pathotypes 704 or 714 could develop (Delmotte et al., 2008). In year $n+4,6$ isolates of pathotypes 300,304 and 314 were observed, possibly explained, at least for 304 and 314, by the fact that they are virulent over PI6 and, even if they could not infect shoots, in the presence of $P / 8$, they could have grown in the roots of H4. Nevertheless, pathotype variability was considerably less than after continuous cropping of either $\mathrm{H} 2$ (Pl6) and $\mathrm{H} 3$ (P/8).

Pyramiding requires the availability of several different sources of resistance. At present in France, only 2 genes which give resistance to all known pathotypes have been identified and are widely used: P/8 (Bert et al., 2001) and Plarg (Vear et al., 2003; Dussle et al., 2004). It is therefore important to continue research for other sources of major gene resistance, in particular in wild H.annuus or other Helianthus species.
Combinations of 2 genes are simple to use, since hybrid varieties are made with parental lines each containing a different gene, but if 3 or more genes are to be included, molecular markers will be essential to confirm their presence. If the risk of downy mildew is important, farmers need to know whether resistance in a variety is controlled by several genes or by one gene giving resistance to all pathotypes.

Another strategy to improve the durability of downy mildew resistance would be to combine Pl genes with "general" resistance. Ochoa et al. (2007) reported that some wheat varieties showed little susceptibility to virulent pathotypes of yellow rust because of "residual resistance" they contained and which could be used in breeding. Castro et al. (2003) showed that it was possible to combine major genes and partial resistance against barley rusts. The efficiency of such associations depends on the effects of host genotypes and their management, on changes in pathogen aggressiveness. The present study did not show any significant changes in aggressiveness for isolates of pathotype 710, but it should be noted that all the forms of the sunflower hybrid were isogenic for any partial resistance factors independent of Pl genes. It would be useful to measure possible changes in aggressiveness in the presence of sunflower varieties with different levels of partial resistance (Tourvieille de Labrouhe et al., 2008).

Finally, to obtain durable control of sunflower downy mildew, genetic resistance should be combined with other control methods. In France, the results of pathogen variability resulting from introduction of pathotypes from North America (Tourvieille de Labrouhe et al., 2005 and Delmotte et al., 2008) underline the necessity of monitoring plant introductions. Farmers must use crop management methods to reduce risk, with tillage (Calviño et al., 2005) and with rotations, especially after strong attacks. Tourvieille de Labrouhe and Walser (2005) showed that the level of infestation of a field depended on the level of attack 1 or 2 years before. $P$. halstedii has been shown to develop resistance to mefenoxam (isomer of metalaxyl), the only systemic anti downy mildew chemical authorised in France (Albourie et al., 1998) but in the absence of this chemical pathogen resistance is reduced (Tourvieille de Labrouhe, 2003). It should thus only be used in high risk situations or on susceptible experimental sunflower genotypes.

Integrated control, as proposed for other host-pathogen combination (Mundt et al., 2002, McDonald and Linde, 2003, Parlevliet, 2002, and Pink, 2002) combining genetic resistance, crop husbandry and limited use of chemical control should help to improve durable control of sunflower downy mildew

Acknowledgements. We thank OLEOSEM for hybrid seed and for help in the organisation of this work. Financial support was provided by the French Ministry of Agriculture (Convention MCB-13A-Conv01-61.21.43 CETIOM-Tournesol/Mildiou).

\section{REFERENCES}

Albourie JM, Tourvieille J, Tourvieille de Labrouhe D. Resistance to metalaxyl in isolates of the sunflower pathogen Plasmopara halstedii. Eur J Plant Pathol 1998; 104: 235-42.

Bert PF, Tourvieille de Labrouhe D, Philippon J, et al. Identification of a second linkage group carrying genes controlling resistance to downy mildew (Plasmopara halstedii) in sunflower (Helianthus annuus L.). Theor Appl Genet 2001; 103: 992-7.

Bouzidi MF, Badaoui S, Cambon F, et al. Molecular analysis of a major locus for resistance to downy mildew in sunflower with specific PCR-based markers. Theor Appl Genet 2002; 104: 592-600.

Calviño P, Pereyra V, Escande A. Influencia de la siembra directa sobre la cantidad de plantas con sintomatología de mildiu, (Plasmoparahalstedii (Farl)). E-campo.com - el futuro esta en la tierra 2005; 27-ene-05: 3. 
Castro AJ, Capettini F, Corey AE, et al. Mapping and pyramiding of qualitative and quantitative resistance to stripe rust in barley. Theor Appl Genet 2003; 107: 922-30.

de Vallavieille-Pope C. Management of disease resistance diversity of cultivars of a species in single fields: controlling epidemics. CR Biol 2004; 327: 611-20.

Delmotte F, Giresse X, Richard-Cervera S, et al. Single nucleotide polymorphisms reveal multiple introductions into France of Plasmopara halstedii, the plant pathogen causing sunflower downy mildew. Infect Genet Evol 2008; 8: 0-534.

Dussle CM, Hahn V, Knapp V, Bauer E. PIArg from Helianthus argophyllus is unlinked to other downy mildew resistance genes in sunflower. Theor Appl Genet 2004; 109: 1083-6.

Holt J, Chancelor TCB. Modelling the spatio-temporal deployment of resistant varieties to reduce the incidence of rice tungro disease in a dynamic cropping system. Plant Pathol 1999; 48: 453-61.

Lannou C, Mundt CC. Evolution of a pathogen population in host mixtures: rate of emergence of complex races. Theor appl Genet 1997; 94: 991-9.

Leppik EE. Distribution of downy mildew and some others seed-borne pathogens on sunflower. Bull FAO 1962; 10: 126-9.

McDonald BA, Linde C. Pathogen population genetics, evolutionary potential, and durable resistance. Annu Rev Phytopathol 2003; 40: 349-79.

McDonald BA, Linde C. The population genetics of plant pathogens and breeding strategies for durable resistance. Euphytica 2002; 124: 163-80.

Molinero-Demilly V, Walser P, Giroult $C$, et al. Mise au point d'une méthode de conservation à long terme de Plasmopara halstedii, parasite obligatoire, agent du mildiou du tournesol. Cryptogam Mycol 2005; 26: 189-94.

Mouzeyar S, Roeckel-Drevet P, Gentzbittel L, et al. RFLP and RAPD mapping of sunflower P/1 locus for resistance to Plasmopara halstedii race 1. Theor Appl Genet 1995; 91: 733-7.

Mundt CC, Cowger C, Garrett K. Relevance of integrated management to disease durability. Euphytica 2002; 124: 245-52.

Ochoa J, Danial DL, Paucar B. Virulence of wheat yellow rust races and resistance genes of wheat cultivars in Ecuador. Euphytica 2007; 153: 287-93.

Parlevliet JE. Durability of resistance against fungal, bacterial and viral pathogens: present situation. Euphytica 2002; 124: 147-56.

Pink DAC. Strategies using genes for non-durable disease resistance. Euphytica 2002; 124: 227-36.

Radwan O, Bouzidi MF, Vear F, et al. Identification of non-TIR-NBS-LRR markers linked to the PI5/P/8 locus for resistance to downy mildew in sunflower. Theor Appl Cenet 2003; 106: 1438-46.

Radwan O, Mouzeyar S, Nicolas P, et al. Induction of a sunflower CC-NBS-LRR resistance gene analogue during incompatible interaction with Plasmopara halstedii. J Exp Bot 2005; 56: 567-75.

Roeckel-Drevet P, Gagne G, Mouzeyar S, et al. Colocation of downy mildew (Plasmopara halstedii) resistance genes in sunflower (Helianthus annuus). Euphytica 1996; 91: 225-8.

Sakr N. Analyse du coût de virulence chez Plasmopara halstedii, I'agent du mildiou du tournesol. Doctorat, Clermont-Ferrand, Université Blaise Pascal. DU 1835: 135 p, 2008.
Sakr N, Ducher M, Tourvieille J, et al. A method to measure aggressiveness of Plasmopara halstedii (Sunflower Downy Mildew). J Phytopathology 2009; 157: 133-6.

Sullivan MJ, Melton TA, Shew HD. Managing the race structure of Phytophthora parasitica var. nicotianae with cultivar rotation. Plant Disease 2005; 89: 1285-94.

Tourvieille de Labrouhe D, Vear F, Habouzit J. Culture du tournesol sous tunnel en filet avec humectation contrôlée pour l'étude du Sclerotinia sclerotiorum. Inf Tech CETIOM 1986; 96: 20-8.

Tourvieille de Labrouhe D. La nouvelle nomenclature des races de Plasmopara halstedii, agent du mildiou du tournesol, appliquée aux races françaises. $\mathrm{OCL}$ 1999; 6: 219-22.

Tourvieille de Labrouhe D, Ducher M, Philippon J, et al. Les méthodes d'analyse du mildiou. In: Le mildiou du tournesol. D. Tourvieille de Labrouhe et al. (eds), Versailles : Inra-Éditions, 2000: 53-66.

Tourvieille de Labrouhe D. El Mildiu del Girasol, manejar el control en pos de una eficacia durable. $S^{\circ}$ Congreso Argentino de Girasol, 12 y 13 de Agosto de 2003, BA (Argentina), 2004, 63-70.

Tourvieille de Labrouhe D. Faire durer la résistance au mildiou du tournesol. Rencontres Annuelles du CETIOM. 30 novembre-1 décembre, Paris (France), 2004, 67-73.

Tourvieille de Labrouhe $D$, Walser $P$. Un test simple pour déceler le mildiou sur une parcelle. Oléoscope 2005; 83: 12.

Tourvieille de Labrouhe $D$, Mestries E, Walser P. Quelles perspectives pour la lutte génétique vis-à-vis du mildiou du tournesol ? OCL 2005; 12: 85-93.

Tourvieille de Labrouhe D, Serre F, Walser P, et al. Quantitative resistance to downy mildew (Plasmopara halstedii) in sunflower (Helianthus annuus). Euphytica 2008; 164: 433-44.

Tourvieille de Labrouhe D, Penaud A, Walser $P$, et al. Determine the "sunflower downy mildew" risk by soil analysis. In Proc. of $7^{\text {th }}$ Int. Sunflower Conf., Cordoba (Spain) 2008; 1: 169-75.

Tourvieille de Labrouhe $D$, Walser $P$, Serre $F$, et al. Variabilité de l'agressivité de Plasmopara halstedii, étude de sa stabilité en test de laboratoire. OCL 2009; 16 : 52-7.

Vear F, Gentzbittel L, Philippon J, et al. The genetics of resistance to five races of downy mildew (Plasmopara halstedii) in sunflower (Helianthus annuus L.). Theor Appl Genet 1997; 95: 584-9.

Vear F, Philippon ], Roche S, et al. Genetical analyses of the sunflower downy mildew resistance gene PI5. In Proc. of $15^{e}$ Conf. Int. sur le Tournesol, 12-15 juin, Toulouse (France), 2000, II : J-31-J-36.

Vear F, Tourvieille de Labrouhe D, Miller JF. Inheritance of the wide-range downy mildew resistance in the sunflower line Rha419. Helia 2003; 26: 19-24.

Vear F, Serre F, Jouan-Dufournel, et al. Inheritance of quantitative resistance to downy mildew (Plasmopara halstedii) in sunflower (Helianthus annuus L.). Euphytica 2008, 164: 561-70.

Zhu Y, Chen H, Fan J, et al. Genetic diversity and disease control in rice. Nature 2000; 406: 718-22. 